\title{
Phytostabilization of metals by indigenous riparian vegetation
}

\author{
Klaudia Schachtschneider ${ }^{1,2 *}$, Jessica Chamier $^{1,3}$ and Vernon Somerset ${ }^{1,4}$ \\ ${ }^{1}$ CSIR, Natural Resources and the Environment, PO Box 320, Stellenbosch 7599, South Africa \\ ${ }^{2}$ WWF-SA PO Box 23273, Claremont 7735, Cape Town, South Africa \\ ${ }^{3}$ HySA Catalysis, University of Cape Town, Rondebosch 7701, South Africa \\ ${ }^{4}$ Cape Peninsula University of Technology, Chemistry Department, Bellville 7535, Cape Town, South Africa
}

\begin{abstract}
Given the increasing pressure of man-made activities on riparian zones, the capacity of the riparian vegetation along the Upper Olifants River, South Africa, to phytoextract and phytostabilize aluminium (Al), manganese $(\mathrm{Mn})$ and iron $(\mathrm{Fe})$ from the soil was investigated. The aim of the study was to gain better understanding of the capacity of indigenous vegetation in riparian zones to immobilize metals in the soil, thereby improving river water quality and ecosystem services. Seven commonly-occurring pollution-tolerant riparian plant species were evaluated to establish their potential as bioaccumulators for Fe, Al and Mn. Species included: Cyperus haspan, Schoenoplectus corymbosus, Typha capensis, Phragmites australis, Cynodon dactylon, Cyperus marginatus and Juncus effusus, which were sampled in five riparian areas in the Upper Olifants catchment. The bioconcentration factor (BCF) for Mn was $>1$ for all species investigated with a maximum of 5 for Typha capensis, which also showed the highest accumulation of $\mathrm{Al}$ (10.26) and $\mathrm{Fe}$ (7.03). The remaining species presented with $\mathrm{Al}$ and Fe BCF between 0.11 and 2.00, with minimal transfer from root to shoot. When measured against an ideal hypothetical buffer zone, the buffer zones under investigation varied between intact and severely compromised. Intact riparian zones showed elevated metal concentrations in the soil, yet significantly lower concentrations in the river water compared to areas with insufficient vegetative cover. A polluted riparian area overgrown by $P$. australis effectively phytoextracted $204960 \mathrm{~g} / \mathrm{m}^{2}$ $\mathrm{Al}, 204400 \mathrm{~g} / \mathrm{m}^{2} \mathrm{Fe}$ and $27887 \mathrm{~g} / \mathrm{m}^{2} \mathrm{Mn}$. The two indigenous Cyperus spp. were not ideal for metal immobilization with low bioaccumulation and transfer factors as well as low biomass. High biomass and $\mathrm{Al}, \mathrm{Fe}$ and $\mathrm{Mn}$ phytostabilizing species: $P$. australis, T. capensis, S. corymbosus and J. effusus, should be considered in the rehabilitation of South African buffer areas.
\end{abstract}

Keywords: riparian vegetation, heavy metals, acid mine drainage, phytostabilization, bioaccumulation

\section{INTRODUCTION}

Riparian vegetation increases resistance and surface roughness, slowing, intercepting and otherwise influencing overland, subsurface and groundwater flows (Welsch, 1991). Natural plant species composition and the extent of the riparian zone vary from region to region and depend on factors such as climate, geology, geomorphology, slope and biome (Gregory et al., 1991; Tilman et al., 1997). An internationally recommended riparian buffer width, optimising the protection of water quality and all other ecosystem services, is 5-30 m (Broadmeadow and Nisbet, 2004; Fischer and Fischenich, 2000; Jontos 2004). Many riparian zones worldwide are being degraded by infringing land use practices such as livestock grazing, agriculture or urbanization, alien plant invasions or increased pollution levels in the catchment (Clericia et al., 2014; Wantzen et al., 2013). These activities reduce the capacity of riparian zones to perform their ecosystem services, further degrading the integrity of the surrounding ecosystem.

The Olifants River is one of South Africa's most polluted catchments, in which urbanisation, mining and agriculture have been ongoing and expanding for more than a century (Driescher, 2008; Oberholster et al., 2010). For the Olifants River catchment, the riparian vegetation not only provides bank stabilization and retains pollutants from surface runoff, it is also exposed to increasing metal concentrations accumulating in the soil, deposited from upstream mining practices. The most common

*To whom all correspondence should be addressed.

Tel: +27 021657 6600; E- mail: kschacht@wwf.org.za

Received 27 January 2016; accepted in revised form 6 March 2017 metals prevalent in the Olifants River catchment are aluminium (Al), iron (Fe) and manganese (Mn) (Oberholster et al, 2010; Tiwary, 2001) leached from the earth by acid mine drainage (AMD). Both Fe and Mn are essential nutrients; their toxicity, however, depends on the dosage, and these metals can become toxic in acidic, sulphate-rich soils (Asch et al., 2005; DWAF, 1996; Duncan, 1999).

The ability of particular plant species to tolerate and remediate certain kinds of pollution, through either phytoextraction or phytostabilization, can be used advantageously in river pollution control and rehabilitation efforts. In phytoextraction, selected plants accumulate high concentrations of metals in their shoot tissue, making it possible to harvest and sometimes even use them as a metal resource (O’Niell and Nzengung, 2004; USEPA, 2000). Phytostabilization means that plants stabilize or immobilize the metals in the soil, thereby delaying and reducing metal transport downstream. Phytostabilization is achieved through the root growth and minimal translocation of metals from the root to shoot or organic litter (Mertens et al., 2004). Any restoration efforts that use phytoextraction and phytostabilization need to carefully consider that selected species are acclimatised to surrounding conditions and that selected plant species show rapid propagation and high biomass.

Firstly, the current study determined the water quality of riparian zones with varying degrees of intactness. Considering these study areas, the photostabilizing capacities of 7 species, common to the existing Olifants River's riparian vegetation zone, were established. These investigations then aimed to determine whether these species would prove useful in river rehabilitation efforts, possibly improving river water quality with depleting 
riparian buffer zones. These species include; Cyperus haspan, Schoenoplectus corymbosus, Typha capensis, Phragmites australis, Cynodon dactylon, Cyperus marginatus and Juncus effusus. Many of these species have previously been recorded to take up various heavy metals to varying degrees. In addition, this study included two locally common species, Cyperus haspan and Cyperus marginatus.

\section{METHODS AND MATERIALS}

\section{Study area}

The Upper Olifants catchment receives summer rainfall, ranging between $550 \mathrm{~mm} / \mathrm{a}$ to $900 \mathrm{~mm} / \mathrm{a}$, while winters are very dry. The upper catchment vegetation types are primarily grassland and bushveld (Mucina and Rutherford, 2006). Previous riparian vegetation assessments have classified different vegetation zones along the macrochannel, consisting of various combinations of trees, shrubs, dwarf shrubs, forbs (herbaceous) and grasses (Myburgh and Breedenkamp, 2004).

Two sampling trips and time series mapping were conducted for 5 study sites in the Upper Olifants catchment, Mpumalanga Province, South Africa (Fig. 1), over the course of June 2009 and November 2011.

\section{Sample collection}

After the initial species inventory, 7 common, indigenous and evidently pollution-tolerant riparian species were selected. Phragmites australis, Typha capensis, Juncus effusus, Schoenoplectus corymbosus and Cynodon dactylon have been previously recorded to take up various heavy metals (Batty et al., 2000; Deng et al., 2004; Demirezen and Aksoy, 2006; Fitamo and Leta, 2002; Tangahu et al., 2011), warranting their analysis for $\mathrm{Al}, \mathrm{Fe}$ and $\mathrm{Mn}$ uptake; while Cyperus haspan and Cyperus marginatus are two locally common species but are unstudied in terms of their bioaccumulation potential.

The percentage abundance of each species was estimated through observation over a $200 \mathrm{~m}$ long and $60 \mathrm{~m}$ wide stretch of river around the study site (Table 1). It was assumed that $100 \%$ equals the sum of all species present in the $200 \mathrm{~m} \mathrm{x} 60 \mathrm{~m}$ area.

For metal accumulation testing, shoot and root material were collected. Thereafter, $5 \mathrm{~g}$ of each specimen was placed into labelled HDPE sample tubes (Remon et al., 2005). Soil samples were taken from the immediate root zone of each plant sample. Biomass data were collected once-off in 2011. Between 3 and 10 samples of each species were sampled at the 5 sites where they occurred. A square sample size of $20 \mathrm{~cm}$ x $20 \mathrm{~cm}$ was dug out per specimen, ensuring that all root and shoot material was sampled. Samples were rinsed, wrapped into refuse bags and

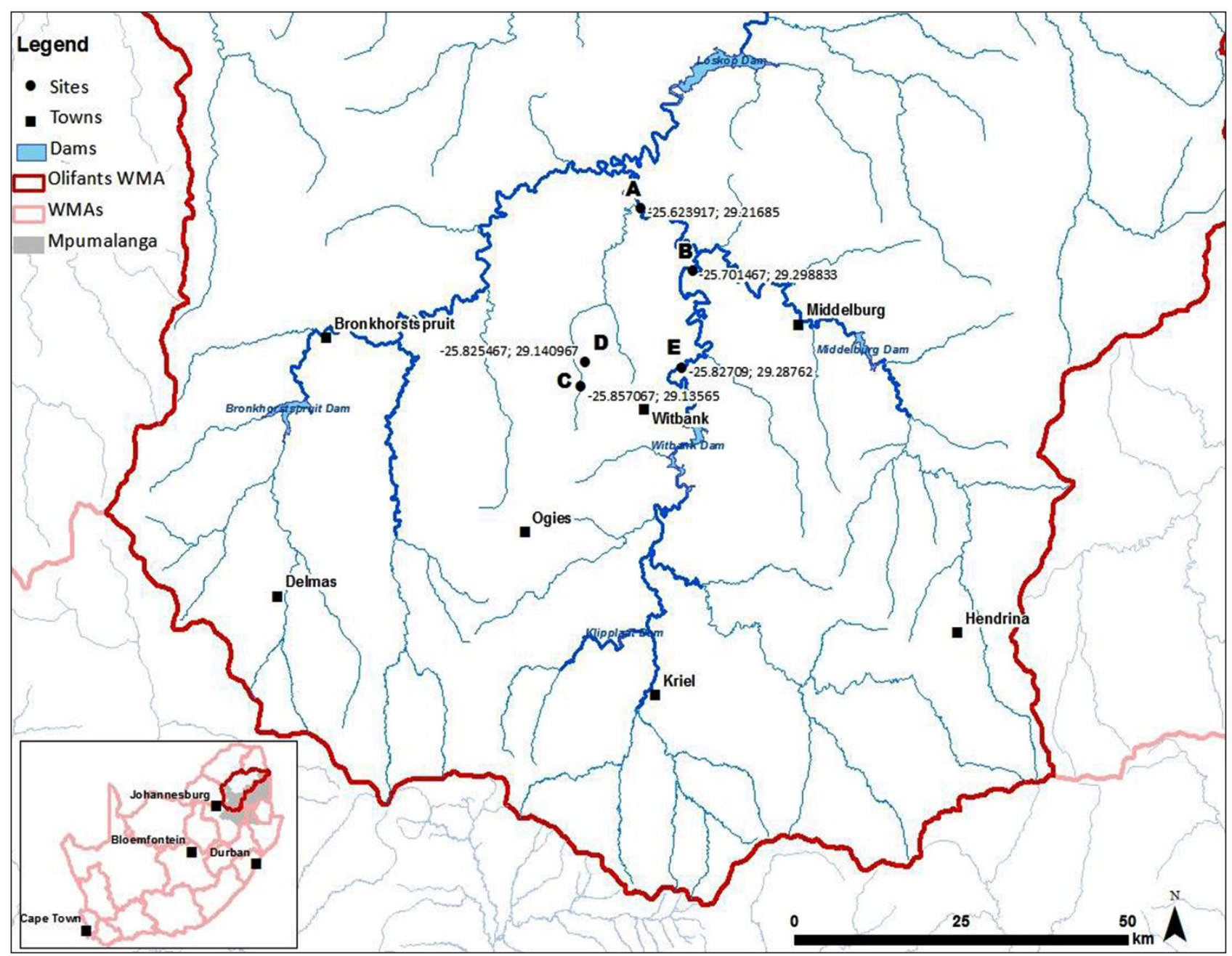

Figure 1

Sampling sites along the Upper Olifants River, Mpumalanga Province, South Africa 
TABLE 1

Species and plant families, their growth form and local abundance (\% of all species present) per site in a $200 \mathrm{~m} \times 60 \mathrm{~m}$ area

\begin{tabular}{|l|l|c|c|c|c|c|}
\hline Species & Growth form & Site A & Site B & Site C & Site D & Site E \\
\hline Cynodon dactylon Linnaeus (Poaceae) & Perennial grass, vegetative cluster & $<1 \%$ & & $2 \%$ & & \\
\hline Cyperus haspan L. (Cyperaceae) & Annual sedge, vegetative cluster & $<1 \%$ & $<1 \%$ & & & \\
\hline Cyperus marginatus Thunb. (Cyperaceae) & Perennial sedge, vegetative cluster & $35 \%$ & $10 \%$ & & & \\
\hline Juncus effusus Linnaeus (Juncaceae) & Perennial, individual specimen & & $5 \%$ & $<1 \%$ & $5 \%$ & $20 \%$ \\
\hline $\begin{array}{l}\text { Phragmites australis (Cavanilles) Trinius } \\
\text { ex Steudel (Poaceae) }\end{array}$ & $\begin{array}{l}\text { Perennial reed with annual shoots, both } \\
\text { growth forms }\end{array}$ & $25 \%$ & $30 \%$ & $98 \%$ & $<1 \%$ & $5 \%$ \\
\hline $\begin{array}{l}\text { Schoenoplectus corymbosus (Roth ex } \\
\text { Roemer \& Schultes) (Cyperaceae) }\end{array}$ & Annual sedge, individual specimen & & & $<1 \%$ & & \\
\hline $\begin{array}{l}\text { Typha capensis (Rohrbach) N.E. Brown } \\
\text { (Typhaceae) }\end{array}$ & Perennial bulrush, both growth forms & & & $1 \%$ & $5 \%$ & $1 \%$ \\
\hline
\end{tabular}

transported in portable ice chests to an accredited laboratory (CSIR, Stellenbosch, South Africa). There, the above-ground (AG) and below-ground (BG) plant parts were separated, washed and left to dry.

The $\mathrm{pH}$ and electrical conductivity values were measured in situ at the water surface using a Hach SensionTM 156 portable multiparameter (Loveland, USA). Duplicate water samples were collected in pre-rinsed, 1-L polyethylene bottles. Water samples were kept cool in the dark and sent to the laboratory for analysis. Total metal concentrations were determined by inductively coupled plasma optical emission spectroscopy (ICP-OES) instrumentation using the APHA et al. (1995) accredited methods.

\section{Soil and plant analysis}

Samples were oven-dried for $24 \mathrm{~h}$ and homogenised with a ball mill. Ground samples were microwave digested, acid diluted, filtered (Ip et al., 2007) and then freeze-dried at $-80^{\circ} \mathrm{C}$ to remove any moisture content which may dilute the solid content metal concentration. Total metal concentrations were determined by ICP-OES instrumentation using the APHA et al. (1995) accredited methods. Data are reported as $\mathrm{mg} / \mathrm{kg}$ dry weight (mg/kg dr. wt). The bioconcentration factor (BCF) (ratio soil: root), translocation factor (TF) (ratio root: shoot) and transfer coefficient (TC) (soil: shoot) were calculated (Yoon et al., 2006).

The extraction efficiency of a plant depends on the metal concentration and the dry weight of harvestable tissue (Bech et al., 2002; Fitamo and Leta, 2010). The capacity of a plant for phytoextraction and phytostabilization was calculated using Eq. 1:

$\mathrm{TPML}=(\mathrm{SL} \times \mathrm{SBM})+(\mathrm{RL} \times \mathrm{RBM})$

where: TPML is the total plant metal levels (in $\mathrm{g} / \mathrm{m}^{2}$ of plant), SL is the shoot level (in $\mathrm{mg} / \mathrm{kg}$ ), SBM is the shoot biomass (in $\mathrm{g} \mathrm{m}^{2}$ ), $\mathrm{RL}$ is the root level (in $\mathrm{mg} / \mathrm{kg}$ ), and $\mathrm{RBM}$ is the root biomass (in $\mathrm{g} / \mathrm{m}^{2}$ ).

\section{GIS mapping of riparian buffer zone}

An area of $2 \mathrm{~km} \times 2 \mathrm{~km}$ was set around the sampling points in which all human land use, including agriculture, mining and urbanization, were mapped. Hard copies of aerial photographs for each site were obtained from the Chief Directorate of National Geospatial Information (CD:NGI), covering aerial surveys undertaken since 1955. Each historical image was scanned and georeferenced using 3 to 5 ground control points
(GCPs) and topographically corrected using a $15 \mathrm{~m}$ digital elevation model (DEM) created from 1:10000 scale contours and spot elevation heights. Orthorectification, geolocational and topographical correction were performed using PCI Geomatica software. The orthorectified images were integrated into GIS applications (ArcMap) to be overlapped and displayed with other GIS data. One of the overlays was the riparian zonation; the other was the $30 \mathrm{~m}$ buffer zone, delineating $30 \mathrm{~m}$ width on each river bank for up to $200 \mathrm{~m}$ upstream and downstream. Final maps compared the areas of actual riparian vegetation to a hypothetical buffer zone of $30 \mathrm{~m}$. Layers were quantified in $\mathrm{km}^{2}$. Statistical differences were analysed by computing the Pearson correlation; $p$-values lower than $p=0.05$ were considered to be significant.

\section{RESULTS AND DISCUSSION}

\section{Bioaccumulation of Al, $\mathrm{Mn}$ and Fe}

The capacity of the seven abundant and widespread riparian plant species (Table 1) to bioaccumulate $\mathrm{Al}, \mathrm{Fe}$ and $\mathrm{Mn}$ was investigated by determining the total metal concentration extracted per plant, root versus shoot tissue accumulation and overall plant biomass (Bech et al., 2002; Fitamo and Leta, 2010). Herein, the possible ecological service they could provide, and potential role in future rehabilitation and remediation efforts along rivers impacted by anthropogenic activities such as acid mine drainage (AMD), could be estimated.

The average root and shoot biomass for the plant species are given in Table 2. Phragmites australis $\left(3371 \mathrm{~g} / \mathrm{m}^{2}\right)$, J. effusus (1 $\left.986 \mathrm{~g} / \mathrm{m}^{2}\right)$ and S. corymbosus $\left(1545 \mathrm{~g} / \mathrm{m}^{2}\right)$ had the highest overall biomass (Table 2). Apart from P. australis, all plants had greater root than shoot biomass.

A plant's ability to accumulate or stabilize metals from soils to its root can be estimated by using the BCF, TF and TC ratios. The TF is the concentration ratio defining the translocation of metals from the roots to the shoots and the TC ratio is that between soil and shoot concentrations (Fitamo and Leta, 2010; Yoon et al., 2006). BCF and TF values greater than 1 are typical indicators for bioaccumulators (Baker, 1981; Baker and Brooks, 1989; Yoon et al., 2006). Plants are considered useful phytostabilizers if metal concentrations are particularly high in the root system (Fitamo and Leta, 2010). The bioaccumulation factors for the plant species investigated in the Olifants River catchment are shown in Table 2. 


\begin{tabular}{|c|c|c|c|c|c|c|c|c|c|c|c|}
\hline \multicolumn{12}{|c|}{ 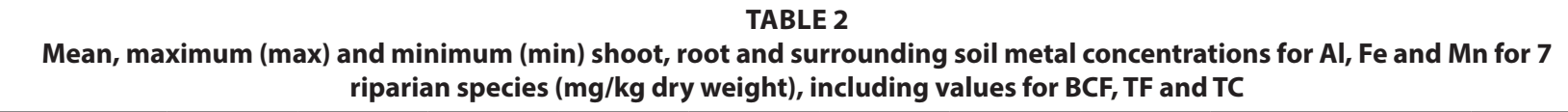 } \\
\hline \multirow{2}{*}{ Species } & \multirow{2}{*}{ Sample } & \multirow{2}{*}{$\begin{array}{l}\text { Average } \\
\text { biomass } \\
\left(\mathrm{g} / \mathrm{m}^{2)}\right.\end{array}$} & \multicolumn{3}{|c|}{ Al (mg/kg dry weight) } & \multicolumn{3}{|c|}{$\mathrm{Fe}$ (mg/kg dry weight) } & \multicolumn{3}{|c|}{ Mn (mg/kg dry weight) } \\
\hline & & & Mean & Min & Max & Mean & Min & Max & Mean & Min & Max \\
\hline \multirow{6}{*}{$\begin{array}{l}\text { S. } \\
\text { corymbosus } \\
(n=10)\end{array}$} & Shoot & 489 & 558 & 114 & 3688 & 801 & 165 & 3755 & 522 & 280 & 1090 \\
\hline & Root & 1055 & 7205 & 1024 & 98027 & 10808 & 2567 & 61477 & 563 & 155 & 3564 \\
\hline & Soil & & 25622 & 21415 & 28671 & 23974 & 19607 & 27027 & 149 & 114.3 & 192.9 \\
\hline & BCF & & 2.14 & 1.21 & 3.57 & 2.33 & 1.6 & 3.13 & 2 & 1.03 & 3.32 \\
\hline & TF & & 0.08 & 0.03 & 0.4 & 0.09 & 0.03 & 0.25 & 1.11 & 0.31 & 2.95 \\
\hline & TC & & 0.14 & 0.11 & 0.17 & 0.17 & 0.13 & 0.21 & 2.63 & 2.04 & 3.05 \\
\hline \multirow{6}{*}{$\begin{array}{l}\text { C. dactylon } \\
(n=7)\end{array}$} & Shoot & 72 & 1662 & 237 & 7434 & 1629 & 211 & 7697 & 268 & 169 & 535 \\
\hline & Root & 688 & 10750 & 3662 & 44522 & 11186 & 3486 & 52883 & 339 & 71 & 1252 \\
\hline & Soil & & 30700 & 7915 & 69213 & 27954 & 7603 & 60961 & 224 & 69.1 & 423 \\
\hline & B CF & & 0.62 & 0.46 & 0.75 & 0.79 & 0.45 & 1.05 & 1.55 & 0.65 & 2.96 \\
\hline & TF & & 0.43 & 0.03 & 1.34 & 0.43 & 0.02 & 1.13 & 1.05 & 0.27 & 2.86 \\
\hline & TC & & 0.2 & 0.02 & 0.53 & 0.2 & 0.06 & 0.51 & 1.57 & 0.81 & 2.95 \\
\hline \multirow{6}{*}{$\begin{array}{l}\text { P. australis } \\
(n=12)\end{array}$} & Shoot & 1709 & 358 & 80 & 1598 & 264 & 72 & 955 & 74 & 39 & 223 \\
\hline & Root & 1661 & 9312 & 7136 & 18031 & 6494 & 1007 & 18323 & 686 & 207 & 4481 \\
\hline & Soil & & 19788 & 18758 & 20875 & 11826 & 11553 & 12107 & 134 & 127 & 142 \\
\hline & BCF & & 0.44 & 0.29 & 0.65 & 0.11 & 0.07 & 0.14 & 1.23 & 0.82 & 1.63 \\
\hline & TF & & 0.04 & 0.01 & 0.18 & 0.14 & 0.01 & 0.64 & 0.22 & 0.61 & 0.65 \\
\hline & TC & & 0.08 & 0.07 & 0.08 & 0.05 & 0.04 & 0.05 & 0.77 & 0.53 & 1 \\
\hline \multirow{6}{*}{$\begin{array}{l}\text { T. capensis } \\
(n=5)\end{array}$} & Shoot & 336 & 845 & 246 & 2146 & 845 & 264 & 4325 & 1487 & 1212 & 2737 \\
\hline & Root & 439 & 58834 & 3533 & 192155 & 47262 & 3491 & 108941 & 448 & 257 & 727 \\
\hline & Soil & & 23886 & 9480 & 196140 & 21537 & 8426 & 169578 & 104 & 42 & 300 \\
\hline & BCF & & 10.09 & 0.6 & 18.5 & 7.03 & 0.63 & 12.9 & 5.84 & 2.42 & 12.2 \\
\hline & TF & & 0.04 & 0.01 & 0.12 & 0.04 & 0.01 & 0.12 & 3.91 & 1.67 & 6.51 \\
\hline & TC & & 0.09 & 0.01 & 0.23 & 0.11 & 0.01 & 0.29 & 29.69 & 4 & 59.6 \\
\hline \multirow{6}{*}{$\begin{array}{l}\text { C. } \\
\text { marginatus } \\
(n=6)\end{array}$} & Shoot & 222 & 176 & 71 & 409 & 220 & 66 & 367 & 176 & 29 & 421 \\
\hline & Root & 369 & 1539 & 133 & 7405 & 1948 & 610 & 4554 & 134 & 26 & 1069 \\
\hline & Soil & & 21015 & 17561 & 26448 & 14248 & 11241 & 20774 & 390 & 1015 & 81 \\
\hline & BCF & & 0.35 & 0.09 & 0.7 & 0.08 & 0.06 & 0.1 & 0.39 & 0.2 & 0.81 \\
\hline & TF & & 0.17 & 0.03 & 0.53 & 0.15 & 0.04 & 0.4 & 2.57 & 0.2 & 6.53 \\
\hline & TC & & 0.01 & 0.01 & 0.02 & 0.02 & 0.01 & 0.02 & 0.08 & 0.02 & 0.14 \\
\hline \multirow{6}{*}{$\begin{array}{l}\text { C. haspan } \\
(n=7)\end{array}$} & Shoot & 68 & 1098 & 210 & 19395 & 744 & 323 & 2124 & 258 & 184 & 405 \\
\hline & Root & 483 & 9029 & 1929 & 28292 & 4471 & 1820 & 8069 & 300 & 74 & 2264 \\
\hline & Soil & & 24746 & 19919 & 29573 & 18176 & 17052 & 19375 & 202 & 72 & 569 \\
\hline & BCF & & 0.98 & 0.54 & 1.42 & 0.13 & 0.09 & 0.17 & 0.68 & 0.33 & 1.03 \\
\hline & TF & & 0.29 & 0.03 & 0.68 & 0.26 & 0.09 & 0.74 & 1.24 & 0.09 & 2.19 \\
\hline & TC & & 0.54 & 0.1 & 0.97 & 0.08 & 0.03 & 0.13 & 1.49 & 0.71 & 2.26 \\
\hline \multirow{6}{*}{$\begin{array}{l}\text { J. effusus } \\
(n=7)\end{array}$} & Shoot & 449 & 367 & 149 & 2656 & 391 & 167 & 2987 & 103 & 35 & 403 \\
\hline & Root & 1536 & 11824 & 9241 & 27712 & 10015 & 1245 & 34628 & 314 & 135 & 738 \\
\hline & Soil & & 14768 & 7564 & 30629 & 13073 & 7591 & 17760 & 197 & 53 & 375 \\
\hline & BCF & & 0.91 & 0.3 & 1.6 & 1.05 & 0.07 & 2.19 & 1.96 & 0.42 & 4.27 \\
\hline & TF & & 0.04 & 0.01 & 0.09 & 0.07 & 0.01 & 0.26 & 0.63 & 0.06 & 2.11 \\
\hline & TC & & 0.04 & 0.01 & 0.16 & 0.05 & 0.02 & 0.19 & 0.96 & 0.13 & 4.15 \\
\hline
\end{tabular}


Given the varying degrees of human impact and pollution, the nature of the plants and the natural geology, the metal concentrations of plant materials varied hugely between specimens and sites. The average metal concentration in the soil varied between $16.047 \mathrm{mg} / \mathrm{kg}$ and $47.045 \mathrm{mg} / \mathrm{kg}$ for $\mathrm{Al}$, $13.23 \mathrm{mg} / \mathrm{kg}$ and $41.719 \mathrm{mg} / \mathrm{kg}$ for Fe and $170-1200 \mathrm{mg} /$ $\mathrm{kg}$ for $\mathrm{Mn}$. The root concentrations of $\mathrm{Al}$ and Fe exceeded the shoot concentrations and only T. capensis (Al) and J. effusus ( $\mathrm{Al}$ and $\mathrm{Fe}$ ) presented root concentrations exceeding soil concentrations. Mn uptake patterns differed to those of $\mathrm{Al}$ and $\mathrm{Fe}$, in that only C. marginatus did not have higher root concentrations of $\mathrm{Mn}$ than what was available in the soil (0.135 - $0.390 \mathrm{mg} / \mathrm{kg}$ ). Typha capensis had Mn shoot concentrations $(1.619 \mathrm{mg} / \mathrm{kg})$ exceeding root concentrations $(0.481 \mathrm{mg} / \mathrm{kg})$.

Schoenoplectus corymbosus and T. capensis showed BCFs higher than 1 for all three metals. Additionally, J. effuses had a $\mathrm{BCF}>1$ for Fe and C. dactylon could bioaccumulate $\mathrm{Mn}$ with a $\mathrm{BCF}$ of 1.6. No species had TF and TC values above 1 for $\mathrm{Al}$ or $\mathrm{Fe}$, whereas for $\mathrm{Mn}, \mathrm{C}$. dactylon, S. corymbosus and T. capensis had TF and TCs ranging from 1.05 to as high as 29. The plant species did not accumulate $\mathrm{Al}, \mathrm{Fe}$ or Mn beyond $10000 \mathrm{mg} / \mathrm{kg}$ of biomass, and are thus not considered hyperaccumulators of these particular metals. $\mathrm{Al}$ and $\mathrm{Fe}$ did not readily transfer into plant shoot tissue for any of the species, but were rather held within the root tissue zone. This would suggest that the species showed greater potential to adsorb and phytostabilize $\mathrm{Al}$ and $\mathrm{Fe}$ in the soil, rather than phytoextract these metals into the above-ground plant material.

Figure 2 depicts the extraction efficiency of all 7 species for $\mathrm{Al}, \mathrm{Fe}$ and $\mathrm{Mn}$. The metal concentrations in the respective shoot and root biomass were determined $\left(\mathrm{g} / \mathrm{m}^{2}\right)$. Al and Fe are almost exclusively trapped in the roots of all species and none accumulate significant concentrations in their shoots. $\mathrm{Mn}$ is more readily accumulated in the shoots, especially by T. capensis $\left(0.8 \mathrm{~g} / \mathrm{m}^{2}\right)$ and S. corymbosus $\left(1.1 \mathrm{~g} / \mathrm{m}^{2}\right)$. Given their higher biomass, S. corymbosus, T. capensis and P. australis would be the most effective phytoextractors of $\mathrm{Mn}$.

There are no previous reports on the metal accumulation ability of the 2 indigenous species, C. haspan and C. marginatus. In the current study, C. haspan and C. marginatus presented with the lowest biomass and neither of the species showed an affinity for the absorption of $\mathrm{Al}, \mathrm{Fe}$ and $\mathrm{Mn}$ from the soil into the plant tissue. These species will therefore not be ideal for metal immobilization in contaminated soils and water.

Typha capensis, S. corymbosus and J. effusus present with the greatest potential to concentrate and phytostabilize $\mathrm{Al}$ and Fe. Given the greater biomass of S. corymbosus and J. effusus (Table 2), these 2 species proved to be the most effective of the 7 species to phytostabilize $\mathrm{Al}$ and $\mathrm{Fe}$ in the root zone (Fig. 2). Internationally, the genus Juncus is popular for use in constructed wetlands for margin and embankment stabilization (Tanner, 1996). In particular J. effusus has shown accumulation of $\mathrm{Fe}, \mathrm{Pb}, \mathrm{Zn}, \mathrm{Cd}$ and $\mathrm{Cu}$ in polluted soils and it is already used elsewhere in constructed wetlands for AMD remediation (Deng et al., 2004; Mays and Edwards, 2001). Schoenoplectus species, in comparison, are known for significant nutrient uptake in highflow artificial wetlands (Vymazal, 2011); however, little is known regarding the metal uptake capacity of S.corymbosus specifically.

Although $P$. australis presents with a reasonably low BCF compared to the other plant species, its total biomass is between 2 and 7 times larger, allowing for larger areas of extraction. Phragmites australis have known benefits in wetlands, i.e., erosion control and filtering of sewage water (Armstrong and Armstrong, 1988; Bromilow, 2010). They are tolerant of extreme $\mathrm{pH}$ differences (Batty et al., 2000) and highly eutrophic conditions with nutrient and heavy metal accumulation $(\mathrm{Cr}, \mathrm{Ni}$, $\mathrm{Cu}$ and $\mathrm{Zn}$ ) capability (Bragato et al., 2006; Wang and Jia, 2009).

Members of the genus Typha have also previously been shown to accumulate other metals $(\mathrm{Cd}, \mathrm{Cu}, \mathrm{Ni}$ and $\mathrm{Pb})$ and are well-known species considered for wetland rehabilitation (Mays and Edwards, 2001). The large biomass of $P$. australis available for metal uptake and the high metal accumulation per $\mathrm{m}^{2}$ of biomass observed for T. capensis should make these species key role players in rehabilitation scenarios.

\section{Riparian vegetation zones}

The GIS mapping to map the extent of the riparian zone against a hypothetical buffer zone of $30 \mathrm{~m}$ is shown in Fig. 3. The difference in area between the ideal buffer width

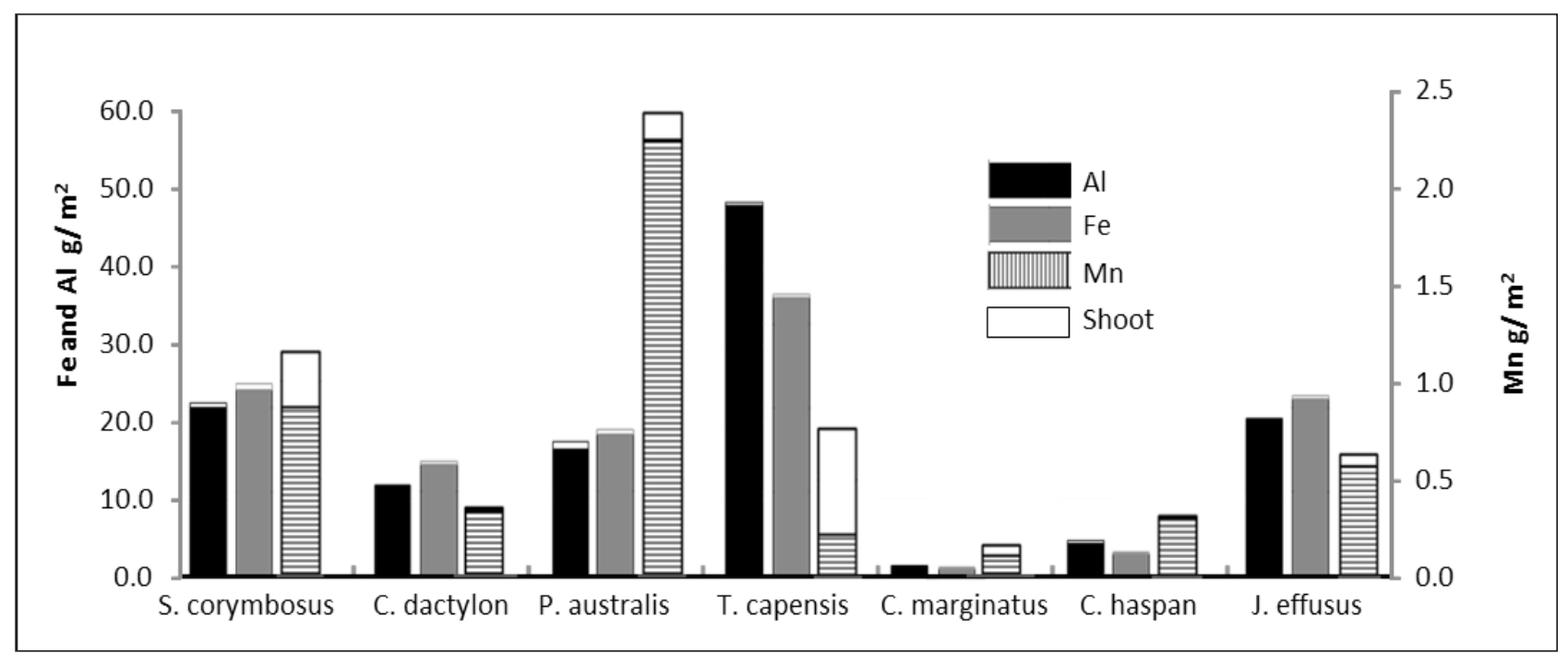

Figure 2

The accumulation potential for $\mathrm{Al}$, Fe and $\mathrm{Mn}$ in $\mathrm{g} / \mathrm{m} 2$ of each of the plant species. 
( $200 \mathrm{~m} \mathrm{x} 60 \mathrm{~m}$ ) and the actual extent of the riparian zone is expressed as a percentage in Table 3 . The ideal buffer increased over $100 \%$ for Site C, due to the included consideration of substantial in-stream vegetation, primarily $P$. australis.

The spatial analysis of the 5 sampling sites in the upper Olifants catchment suggests that the riparian zones within the catchment are in various states of degradation/intactness. From the natural distribution of species at the 5 study sites in the Olifants River catchment (Table 1) in a hypothetical riparian zone of $12000 \mathrm{~m}^{2}$, the total $\mathrm{Al}, \mathrm{Fe}$ and $\mathrm{Mn}$ accumulated in the separate plant biomass per site is estimated in Fig. 4. Due to the high biomass and relative abundance, $P$. australis that was the main phytostabilizer of metals in Sites B and C whereas $T$. capensis and J. effusus were the primary stabilizers at Site D and Site E, respectively.

To qualify the possible ecological ecosystem service provided by the riparian species and their capability of photostabilizing $\mathrm{Al}, \mathrm{Fe}$ and $\mathrm{Mn}$ in the study sites, the average water and soil metal concentrations were compared. The average water and soil concentrations of $\mathrm{Al}, \mathrm{Fe}$ and $\mathrm{Mn}$ along with the intactness of the riparian area are presented in Fig. 6. Seasonal sampling had higher metal and nutrient concentrations during the high-flow months. The $\mathrm{pH}$ and electrical conductivity of water samples collected from Sites A and B ranged between $\mathrm{pH} 7.6$ and $\mathrm{pH}$ 7.7 and 47 and $52.2 \mathrm{mS} / \mathrm{m}$, respectively. The riparian zones in Sites A and B were mostly intact (70 and $77 \%$, respectively) with minimal anthropogenic disturbances. Although the metal concentrations in the soil determined for these ranged in the medium to high end of the scale, the $\mathrm{Al}, \mathrm{Fe}$ and $\mathrm{Mn}$ concentrations for Sites A and B were low and well within the recommended target water quality guidelines (DWAF, 1996). This is likely due to the absence of major anthropogenic activities and sufficient phytostabilization of the metals in the soil in near-neutral pH conditions. Sites A and B are reference sites which represent the more intact areas with fully functional ecosystem services.

The concentrations of $\mathrm{Mn}, \mathrm{Al}$ and $\mathrm{Fe}$ found in the soil and water vary from site to site and are largely dependent on the surrounding anthropogenic activities as well as the natural geology. Site $\mathrm{C}$ and Site $\mathrm{D}$ showed the highest metal concentrations in water as well as a low pH (between pH 5.3 and 5.4) and high electrical conductivity, ranging on average between

TABLE 3

Most recent data on riparian vegetation, compared to an area calculation of a hypothetical $30 \mathrm{~m}$ buffer zone and the most prevalent land use activities in an area of $2 \mathbf{k m} \times 2 \mathbf{~ k m}$.

\begin{tabular}{|l|c|c|l|}
\hline Site & Year & $\begin{array}{c}\text { \% Ideal } \\
\text { vegetation } \\
\text { intact }\end{array}$ & \multicolumn{1}{|c|}{ Land use practices } \\
\hline Site A & 2005 & 80 & Minimal grazing \\
\hline Site B & 2005 & 77 & $\begin{array}{l}\text { Game farming, limited } \\
\text { agricultural activities, mostly } \\
\text { undisturbed }\end{array}$ \\
\hline Site C & 1991 & 280 & $\begin{array}{l}\text { Major urbanisation, minimal } \\
\text { agriculture, grazing, historical } \\
\text { mining (AMD) }\end{array}$ \\
\hline Site D & 2011 & 13 & $\begin{array}{l}\text { Major livestock grazing, } \\
\text { historical mining (AMD), } \\
\text { industry (VanChem) }\end{array}$ \\
\hline Site E & 2003 & 38 & $\begin{array}{l}\text { Urbanization and agriculture, } \\
\text { just below the outlet of a } \\
\text { wastewater treatment works }\end{array}$ \\
\hline
\end{tabular}

199.5 and $209 \mathrm{mS} / \mathrm{m}$. These water quality conditions coincide with the occurrence of AMD associated with mining activities. $\mathrm{Al}$ and Fe concentrations were similar for most sampling sites indicating that these most likely originated from the natural geology (Newman et al., 2007). Elevated concentrations of Al and Fe are likely due to AMD, which leach these metals from the natural geology, making them more bioavailable (McCauley et al., 2009). $\mathrm{Al}$ and $\mathrm{Fe}$ soil concentrations at Site $\mathrm{C}$ were more than twice as high as in any of the other sites, and can likely be ascribed to metal stabilization in soil through the prolific growth of $P$. australis in and around the river (Wong, 2003; Ashraf et al, 2011). The accumulation potential of $P$. australis in the ideal vegetation zone was effectively phytoextracting $204960 \mathrm{~g} / \mathrm{m}^{2}$ of $\mathrm{Al}, 204400 \mathrm{~g} / \mathrm{m}^{2}$ of Fe and $27887 \mathrm{~g} / \mathrm{m}^{2}$ of Mn into its biomass. The comparatively low metal concentrations in the water could be due to a considerable ecosystem service performed by the naturally established riparian vegetation. The intact vegetation reduced the stream flow, and increased the water $\mathrm{pH}$ as well as phytostabilizing the metals into the soil.

Site D is just downstream of Site C with only $13 \%$ of its riparian vegetation intact. It is under severe pressure from ongoing industrial activities and AMD. Metal concentrations in water were high, while soil $\mathrm{Al}, \mathrm{Fe}$ and $\mathrm{Mn}$ concentrations were lower than those of the reference sites, Sites A and B. One of the overt differences between Sites C and D is the difference in riparian growth, suggesting low to minimal soil metal stabilization. Comparing these sites, it is postulated that a revegetation of the riparian zone at Site $\mathrm{D}$, including native species investigated in this study, may improve pollutant retention and phytostabilization of $\mathrm{Al}, \mathrm{Fe}$ and $\mathrm{Mn}$. As such, metals are retained in the soil and extracted into the plants, reducing metal concentrations in river water. Recommendations for a rehabilitation strategy to remediate elevated metal concentrations ( $\mathrm{Al}, \mathrm{Fe}$ and $\mathrm{Mn}$ ) in this area include:

- Revegetation of the riparian zone to at least $80 \%$ intact (from ideal)

- Using a diversity of native, $\mathrm{pH}$-tolerant plant species

- Increasing the total biomass in the riparian zone by introducing P. australis

- Including high metal uptake (BCF) plants such as T. capensis

- Introducing in-stream vegetation

\section{CONCLUSIONS}

The Al-, Fe- and Mn-sequestering ability of widely occurring species in the Upper Olifants Catchment, South Africa, was determined for their potential inclusion in water quality rehabilitation efforts. None of the plant species proved hyperaccumulators of $\mathrm{Al}, \mathrm{Fe}$ or Mn. However, 4 species, S. corymbosus, T. capensis, P. australis and J. effusus, have accumulation and high phytostabilization potential. $S$. corymbosus and T. capensis, shoot accumulators of $\mathrm{Mn}$, were considered the best candidates for phytoextraction of Mn. Site $\mathrm{C}$ provides an example of successful phytostabilization, aided by a prolific riparian zone, in a severely degraded landscape. Given the similar environmental impacts for Site $\mathrm{D}$, the water quality may be improved by rehabilitating the riparian zone in degraded areas, using a combination of the widely-occurring, pollutiontolerant and Al-, Fe-, Mn-phytostabilizing species: P. australis, T. capensis, S. corymbosus and J. effusus. Furthermore, indigenous species, Cyperus haspan and Cyperus marginatus are less likely 


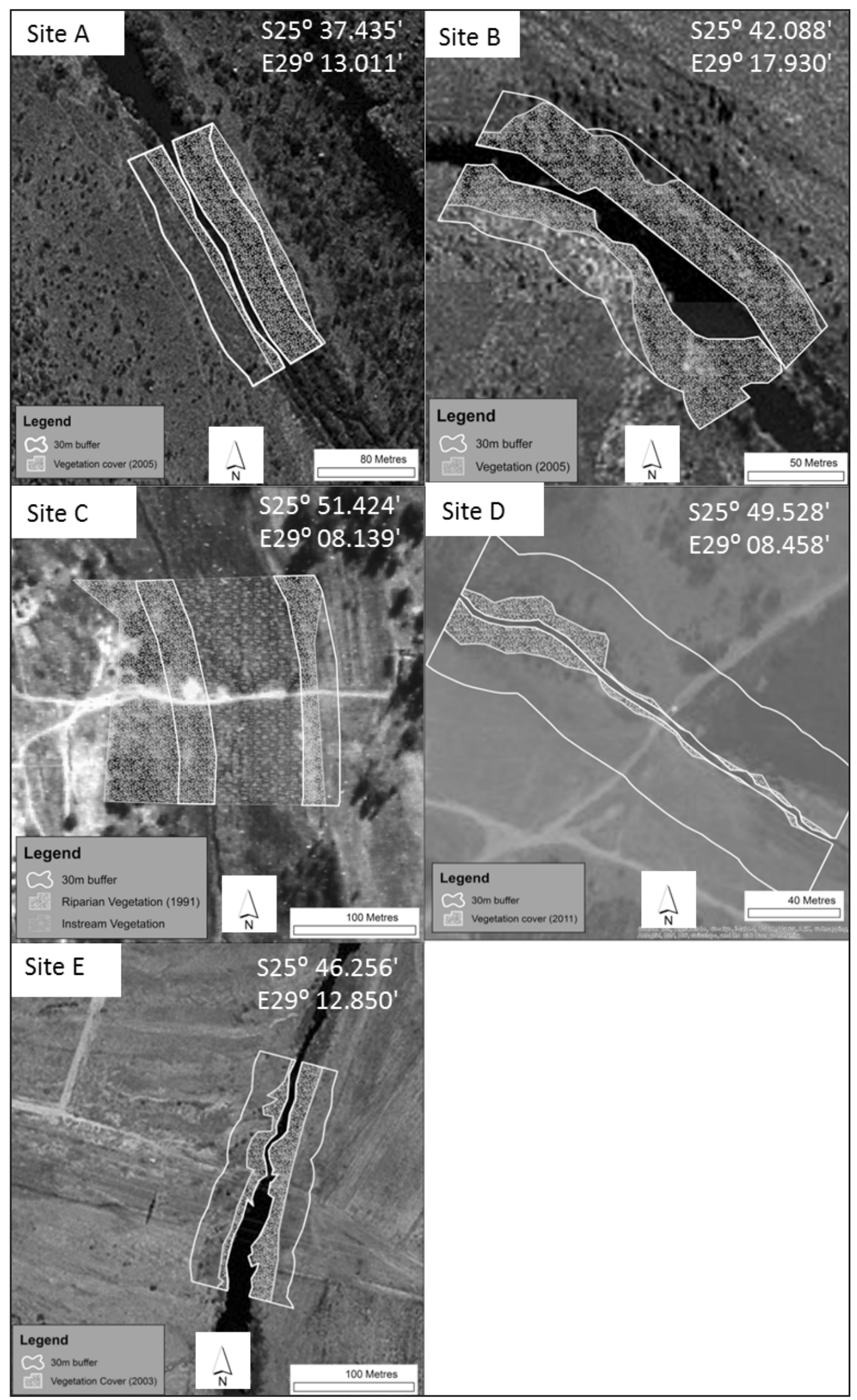

Figure 3

Extent of riparian vegetation zones relative to a hypothetical $30 \mathrm{~m}$ buffer zone for Site A, Site B, Site C, Site D and Site E 


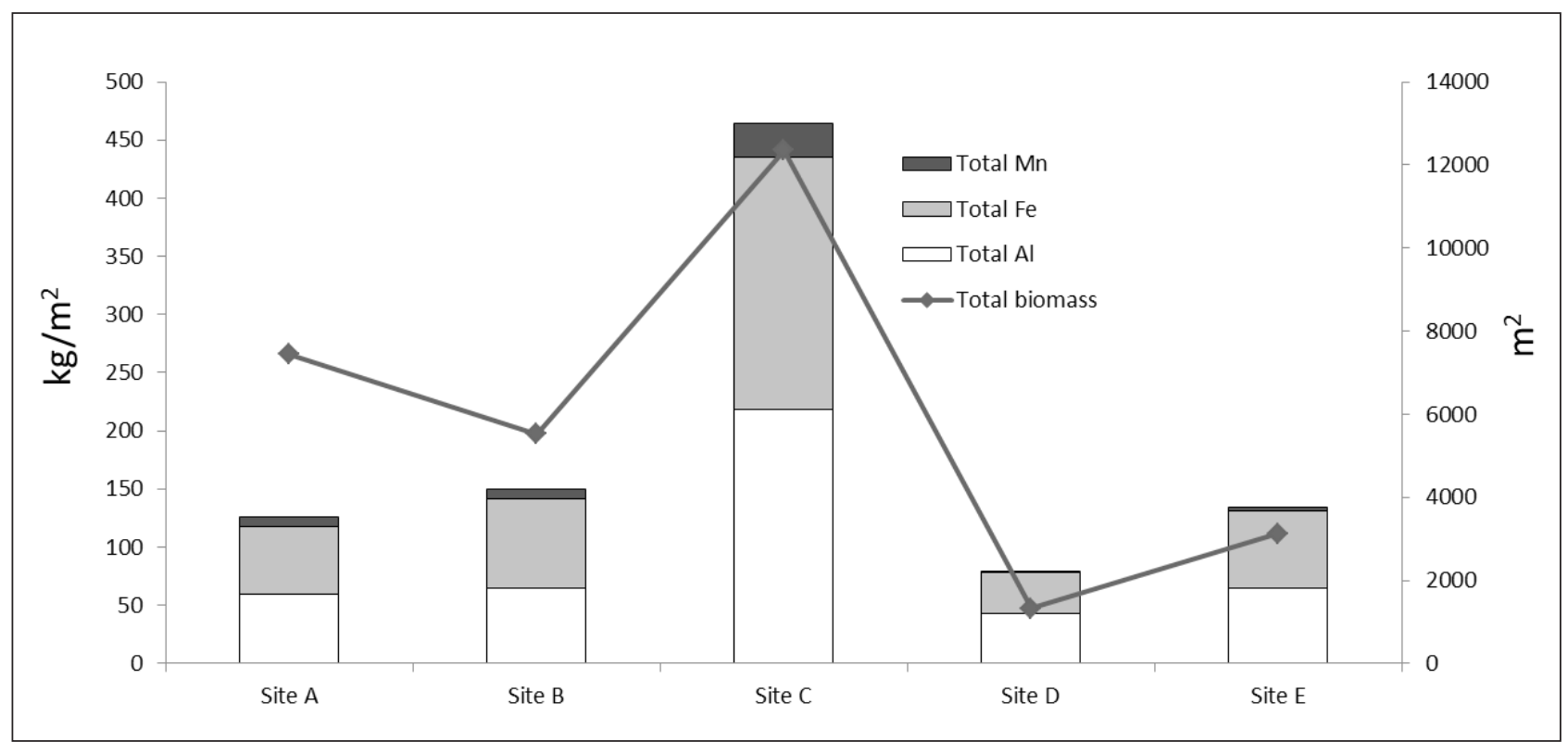

Figure 4

Estimated total metal amounts $(\mathrm{g} / \mathrm{m} 2)$ that the biomass determined from the surveyed distribution of the selected plant species could phytostabilize at the 5 study sites.

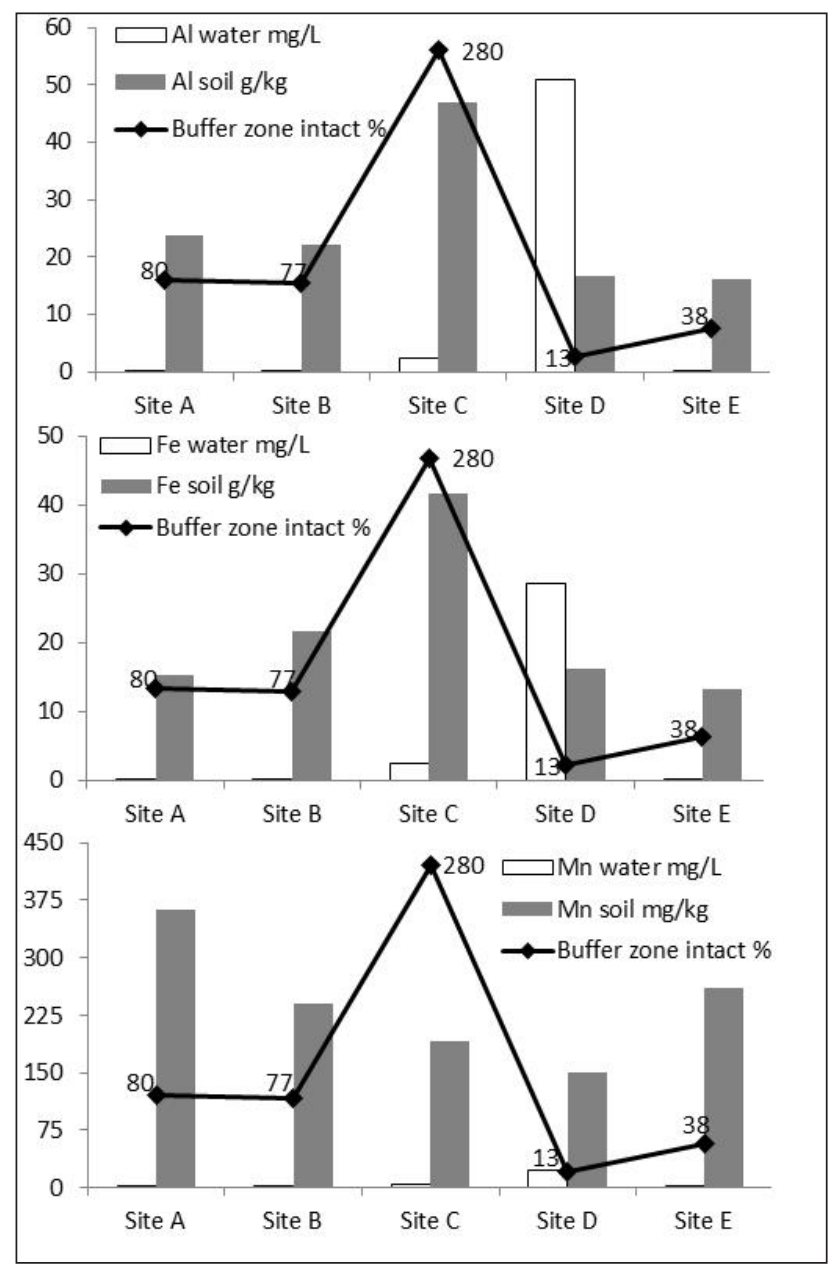

Figure 5

The average water and soil concentrations of $A l$, Fe and Mn determined for the sampling sites with corresponding intact \% vegetated buffer area to occur in areas contaminated by AMD. These species have low biomass and present with low BCF for Al, Fe and Mn. C. haspan and C. marginatus do present with translocation factors $>1$ for the accumulation of $\mathrm{Mn}$, which suggests for their inclusion in rehabilitation studies.

\section{ACKNOWLEDGEMENTS}

We would like to thank the Olifants River Forum for funding.

\section{REFERENCES}

APHA, AWWA and WEF (1995) Standard Methods for the Examination of Water and Wastewater (19th edn). American Public Health Association, Washington DC.

ARMSTRONG J and ARMSTRONG W (1988) Phragmites australis - a preliminary study of soil-oxidizing sites and internal gas transport pathways. New Phytol. 108 373-382. https://doi. org/10.1111/j.1469-8137.1988.tb04177.x

ASCH F, BECKER M and KPONGOR DS (2005) A quick and efficient screen for resistance to iron toxicity in lowland rice. J. Plant Nutr. Soil Sci. 168 (6) 764-773. https://doi.org/10.1002/jpln.200520540

ASHRAF M, MAAH MJ and YUSOFF I (2011) Heavy metals accumulation in plants growing in ex tin mining catchment. Int. J. Environ. Sci. Technol. 8 (2) 401-416. https://doi.org/10.1007/ BF03326227

BAKER AJM (1981) Accumulators and excluders - strategies in the response of plants to heavy metals. J. Plant Nutr. 3 (1-4) 643-654. https://doi.org/10.1080/01904168109362867

BAKER AJM and BROOKS RR (1989) Terrestrial higher plants which hyperaccumulate metallic elements - a review of their distribution, ecology and phytochemistry. Biorecovery 1 (2) 81-126.

BATTY LC, BAKER AJM, WHEELER BD and CURTIS CD (2000) The effect of $\mathrm{pH}$ and plaque on the uptake of $\mathrm{Cu}$ and $\mathrm{Mn}$ in Phragmites australis (Cav.) Trin ex. Steudel. Ann. Bot. 86 (3) 647-653. https://doi. org/10.1006/anbo.2000.1191

BECH J, POSCHENRIEDER C, BARCELO J and LANSAC A (2002) Plants from mine spoils in the South American area as potential sources of germplasms for phytoremediation 
technologies. Acta Biotechnol. 22 (1-2) 5-11. https://doi. org/10.1002/1521-3846(200205)22:1/2<5::AID-ABIO5>3.0.CO;2-B

BRAGATO C, BRIX H and MALAGOLI M (2006) Accumulation of nutrients and heavy metals in Phragmites australis (Cav.) Trin. ex Steudel and Bolboschoenus maritimus (L.) Palla in a constructed wetland of the Venice lagoon watershed. Environ. Pollut. 144 (3) 967-975. https://doi.org/10.1016/j.envpol.2006.01.046

BROADMEADOW S and NISBET TR (2004) The effects of riparian forest management on the freshwater environment: a literature review of best management practice. Hydrol. Earth Syst. Sci. Discuss. 8 (3) 286-305. https://doi.org/10.5194/hess-8-286-2004

BROMILOW C (2010) Problem plants and alien weeds of South Africa, third ed. Briza Publications, Pretoria.

CLERICI N, PARACCHINA ML and MAES J (2014) Land-cover change dynamics and insights into ecosystem services in European stream riparian zones. Ecohydrol. Hydrobiol. 14 (2) 107-120. https://doi. org/10.1016/j.ecohyd.2014.01.002

DWAF (Department of Water Affairs and Forestry, South Africa) (1996) South African Water Quality Guidelines. Volume 1. Domestic Use (2nd edn). Department of Water Affairs and Forestry, Pretoria.

DENG H, YE ZH and WONG MH (2004) Accumulation of lead, zinc, copper and cadmium by 12 wetland plant species thriving in metalcontaminated sites in China. Environ. Pollut. 132 (1) 29-40. https:// doi.org/10.1016/j.envpol.2004.03.030

DUNCAN M (1999) Pastures and acid soils. Leaflet No. 6. New South Wales Acid Soil Action Programme. URL: http://www.dpi.nsw.gov. au/_data/assets/pdf_file/0007/162925/acid-soil.pdf (accessed 12 August 2014).

FISCHER RA and FISCHENICH JC (2000) Design recommendations for riparian corridors and vegetated buffer strips. No. ERDC-TNEMRRP-SR-24. U.S. Army Engineer Research and Development Center, Environmental Laboratory, Vicksburg, MS

FITAMO D and LETA S (2010) Assessment of plants growing on gold mine wastes for their potential to remove heavy metals from contaminated soils. Int. J. Environ. Stud. 67 (5) 705-724. https://doi. org/10.1080/00207233.2010.513587

GREGORY SV, SWANSON FJ, MCKEE WA and CUMMINS KW (1991) An ecosystem perspective of riparian zones. Bioscience 41 540-551. v

JONTOS R (2004) Vegetative buffers for water quality protection: an introduction and guidance document. Connecticut Association of Wetland Scientists White Paper on Vegetative Buffers. Draft version 1.0. Connecticut Association of Wetland Scientists (CWAS). 22 pp.

MAYS PA and EDWARDS GS (2001) Comparison of heavy metal accumulation in a natural wetland and constructed wetlands receiving acid mine drainage. Ecol. Eng. 16 (4) 487-500. https://doi. org/10.1016/S0925-8574(00)00112-9

MCCAULEY CA, O'SULLIVAN AD, MILKE MW, WEBER PA and TRUMM DA (2009) Sulfate and metal removal in bioreactors treating acid mine drainage dominated with iron and aluminium. Water Res. 43 (4) 961-970. https://doi.org/10.1016/j.watres.2008.11.029

MERTENS J, VERVAEKE P, DE SCHRIJVER A and LUYSSAERT $S$ (2004) Metal uptake by young trees from dredged brackish sediment: limitations and possibilities for phytoextraction and phytostabilisation. Sci. Total Environ. 326 (1) 209-215. https://doi. org/10.1016/j.scitotenv.2003.12.010

MUCINA L and RUTHERFORD M (2006) The Vegetation of South Africa, Lesotho and Swaziland. Strelitzia 19. South African National Biodiversity Institute, Pretoria.

MYBURGH WJ and BREDENKAMP GJ (2004) Macro-channel riparian vegetation of the Olifants River System in the Grassland Biome,
Mpumalanga. Koedoe 47 (1) 41-54. https://doi.org/10.4102/koedoe. v47i1.71

NEWMAN BK and WATLING RJ (2007) Definition of baseline metal concentrations for assessing metal enrichment of sediment from the south-eastern Cape coastline of South Africa. Water SA 33 (5) 675-691.

O’NIELL WL and NZENGUNG VA (2004) In-situ bioremediation and phytoremediation of contaminated soils and water: three case studies. Environ. Res. Eng. Manage. 30 49-54.

OBERHOLSTER PJ, MYBURGH JG, ASHTON PJ and BOTHA AM (2010) Responses of phytoplankton upon exposure to a mixture of acid mine drainage and high levels of nutrient pollution in Lake Loskop, South Africa. Ecotox. Environ. Saf. 73 326-335. https://doi. org/10.1016/j.ecoenv.2009.08.011

REMON E, BOUCHARDON JL, CORNIER B, GUY B, LECLERC JC and FAURE O (2005) Soil characteristics, heavy metal availability and vegetation recovery at a former metallurgical landfill: Implications in risk assessment and site restoration. Environ. Pollut. 137 316-323. https://doi.org/10.1016/j.envpol.2005.01.012

TANGAHU BV, SHEIKH ABDULLAH SR, BASRI H, IDRIS M, ANUAR $\mathrm{N}$ and MUKHLISIN M (2011) A review on heavy metals (As, $\mathrm{Pb}$, and $\mathrm{Hg}$ ) uptake by plants through phytoremediation. Int. J. Chem. Eng. 2011 939161. https://doi.org/10.1155/2011/939161

TANNER CC (1996) Plants for constructed wetland treatment systems - A comparison of the growth and nutrient uptake of eight emergent species. Ecol. Eng. 7 59-83. https://doi. org/10.1016/0925-8574(95)00066-6

TILMAN D, KNOPS J, WEDIN D, REICH P, RITCHIE M and SIEMANN E (1997) The influence of functional diversity and composition on ecosystem processes. Science 277 1300-1302. https:// doi.org/10.1126/science.277.5330.1300

TIWARY RK (2001) Environmental impact of coal mining on water regime and its management. Water Air Soil Pollut. 132 185-199. https://doi.org/10.1023/A:1012083519667

USEPA (United States Environmental Protection Agency) (2000) Introduction to phytoremediation. EPA/600/R-99/107. Environmental Protection Agency, Washington, D.C.

VYMAZAL J (2011) Plants used in constructed wetlands with horizontal subsurface flow: a review. Hydrobiologia 674 133-156. https://doi. org/10.1007/s10750-011-0738-9

WANG H and JIA Y (2009) Bioaccumulation of heavy metals by Phragmites australis cultivated in synthesized substrates. J. Environ. Sci. 21 1409-1414. https://doi.org/10.1016/S1001-0742(08)62433-X

WANTZEN KM and MOL JH (2013) Soil erosion from agriculture and mining: a threat to tropical stream ecosystems. Agriculture 3 660683. https://doi.org/10.3390/agriculture3040660

WELSCH DJ (1991) Riparian forest buffers. United States Department of Agriculture-Forest Service Publication Number NA-PR-07-91. US Department of Agriculture, Radnor, Pennsylvania.

WONG MH (2003) Ecological restoration of mine degraded soils, with emphasis on metal contaminated soils. Chemosphere 50 775-780. https://doi.org/10.1016/S0045-6535(02)00232-1

YOON J, CAO X, ZHOU Q and Ma LQ (2006) Accumulation of Pb, $\mathrm{Cu}$ and $\mathrm{Zn}$ in native plants growing on a contaminated Florida site. Sci. Total Environ. 368 456-464. https://doi.org/10.1016/j. scitotenv.2006.01.016 